\title{
PENGGUNAAN MEDIA PEMBELAJARAN EDMODO UNTUK MENINGKATKAN AKTIVITAS DAN HASIL BELAJAR SISWA KELAS X PEMASARAN DI SMK NEGERI 1 JEMBER TAHUN AJARAN 2016/2017
}

\author{
Santhy Rahmawati Putri ${ }^{1}$, Sri Wahyuni ${ }^{1}$, Pudjo Suharso ${ }^{1}$ \\ ${ }^{1}$ Program Studi Pendidikan, Fakultas Keguruan dan Ilmu Pendidikan, Universitas Jember \\ e-mail: sriwahyunipe.fkip@unej.ac.id
}

\begin{abstract}
Abstrak
Pembelajaran merupakan proses penyampaian informasi dari guru kepada siswa. Salah satu unsur yang terdapat dalam proses pembelajaran adalah media. Media pembelajaran diperlukan oleh guru untuk menunjang seluruh aktivitas pembelajaran. Seiring dengan perkembangan teknologi informasi, banyak diciptakan media pembelajaran berbasis internet salah satunya adalah Edmodo. Edmodo dibutuhkan siswa agar dapat aktif dalam kegiatan belajar mengajar baik didalam kelas maupun diluar kelas. SMK Negeri 1 Jember merupakan salah satu sekolah yang sudah mengenal pembelajaran berbasis internet akan tetapi belum menggunakan media Edmodo. Penelitian ini bertujuan untuk meningkatkan aktivitas dan hasil belajar siswa kelas X Pemasaran di SMK Negeri 1 Jember dalam mata pelajaran Pengelolaan Usaha Pemasaran melalui media pembelajaran Edmodo. Penelitian ini merupakan penelitian tindakan kelas. Penelitian dilaksanakan di SMK Negeri 1 Jember tahun ajaran 2016/2017 dengan subyek penelitian kelas X PM 3 berjumlah 39 siswa dan objek penelitian pada mata pelajaran Pengelolaan Usaha Pemasaran. Pengumpulan data menggunakan metode observasi, wawancara, tes dan dokumentasi. Penelitian ini dilakukan dengan menggunakan 2 siklus yang terdiri dari, perencanaan, pemberian tindakan, observasi dan refleksi. Teknik analisis data yang digunakan dalam penelitian ini adalah analisis data aktivitas belajar melalui observasi dan analisis data hasil belajar melalui tes. Hasil penelitian menunjukkan bahwa adanya peningkatan aktivitas belajar dari kondisi awal sebesar $44 \%$ menjadi $60,7 \%$ pada siklus 1 dan meningkat menjadi 92,5\% pada siklus 2. Peningkatan hasil belajar juga dapat dilihat dari nilai ratarata siswa yaitu 66,7 pada kondisi awal meningkat menjadi 72,37 pada siklus 1 dan 80,10 pada siklus 2 . Kesimpulannya bahwa penggunaan media pembelajaran Edmodo ternyata dapat meningkatkan aktivitas dan hasil belajar siswa kelas X PM 3 pada mata pelajaran Pengelolaan Usaha Pemasaran.
\end{abstract}

Kata Kunci: Media pembelajaran, edmodo , aktivitas belajar, hasil belajar

\section{PENDAHULUAN}

Pembelajaran merupakan proses penyampaian informasi pengetahuan dari guru kepada siswa. Ciri-ciri pembelajaran pada dasarnya merupakan tanda-tanda upaya guru mengatur unsur-unsur dinamis dalam pembelajaran, sehingga dapat mengaktifkan siswa dalam kegiatan belajar mengajar agar terjadi proses belajar dan tujuan pembelajaran dapat tercapai. Kegiatan belajar mengajar merupakan suatu kondisi yang sengaja diciptakan dimana dalam kegiatan tersebut terjadi interaksi antara pendidik dan peserta didik guna mewujudkan tujuan pembelajaran itu sendiri.

Kegiatan pembelajaran yang dilakukan pada sekolah menengah kejuruan pada umumnya lebih mengarah kepada pengembangan kompetensi dan keterampilan. Sesuai dengan tujuan SMK adalah sebagai salah satu institusi yang menyiapkan tenaga kerja, dituntut mampu menghasilkan lulusan sebagaimana yang diharapkan oleh dunia kerja. Dengan demikian proses pembelajaran yang dilakukan oleh siswa SMK lebih cenderung secara praktikal, sehingga secara teori pengetahuan mereka lebih sedikit daripada pengalaman mereka ketika praktik.

Saat ini proses pembelajaran tatap muka masih sering digunakan. SMK Negeri 1 Jember juga merupakan salah satu sekolah yang menerapkan pembelajaran tatap muka dengan menggunakan media powerpoint. Penggunaan media powerpoint oleh guru masih belum cukup untuk menunjang kegiatan pembelajaran peserta didik. Berdasarkan observasi awal pada kelas X jurusan Pemasaran, aktivitas 
belajar kelas X PM3 termasuk dalam kategori rendah dibandingkan dengan kelas X PM1 dan X PM2. Aktivitas belajar pada kelas X PM3 hanya mencapai skor $40 \%$. Selain itu hasil belajar pada kelas X PM3 juga masih tergolong rendah, yakni rata-rata nilai ulangan harian masih di bawah KKM yaitu 66,7.

Media merupakan salah satu unsur yang dapat menunjang proses pembelajaran. Menurut Gerlach (dalam Sandjaya, 2012: 59) secara umum media (pembelajaran) itu meliputi orang, bahan, peralatan, atau kegiatan yang menciptakan kondisi yang memungkinkan siswa memperoleh pengetahuan, keterampilan, dan sikap. Jadi dalam pengertian ini media pembelajaran bukan hanya alat perantara, tetapi meliputi orang atau manusia sebagai sumber belajar atau juga berupa kegiatan semacam diskusi, simulasi, dan sebagainya yang dikondisikan untuk menambah pengetahuan dan wawasan, mengubah sikap peserta didik, serta untuk menambah keterampilan. Salah satu prinsip penggunaan media pembelajaran yang harus diperhatikan oleh guru menurut Sandjaya (2012: 75) bahwa media digunakan dan diarahkan untuk mempermudah siswa belajar dalam upaya memahami materi pelajaran.

Seiring dengan perkembangan Teknologi Informasi (TI), banyak diciptakan media yang dapat digunakan untuk menunjang kegiatan pembelajaran. Media pembelajaran berbasis internet atau $E$ Learning saat ini banyak digunakan untuk kegiatan belajar mengajar. Salah satu media yang dapat digunakan untuk menunjang kegiatan dalam pembelajaran yaitu Edmodo. Menurut Gatot (2013: 3) Edmodo adalah platform media sosial yang sering digambarkan seperti Facebook untuk sekolah dan dapat berfungsi lebih banyak lagi sesuai kebutuhan. Edmodo merupakan media yang menarik bagi guru dan peserta didik dengan elemen sosial yang menyerupai Facebook. Seorang guru dapat dengan mudah mengelola sebuah sistem yang menyediakan fitur terbaik dan praktis, sehingga guru selalu terhubung dengan peserta didik dan mengatur aktivitas peserta didik dengan mudah. Kegiatan pembelajaran yang dapat digunakan sesuai dengan fitur yang tersedia pada media Edmodo yakni contet sharing atau berbagi materi pelajaran, penugasan, kuis, polling serta memungkinkan adanya kegiatan diskusi pada fitur komentar.

Menurut Martinis Yamin (2007: 75) proses pembelajaran yang dilakukan di dalam kelas merupakan aktivitas mentransformasikan pengetahuan, sikap, dan keterampilan. Aktivitas merupakan prinsip atau asas yang sangat penting dalam interaksi belajar mengajar (Sardiman, 2006: 96). Pembelajaran akan menghasilkan suatu perubahan dan peningkatan kemampuan pengetahuan serta keterampilan pada diri peserta didik. Aktivitas belajar memiliki beberapa jenis dan indikator dimana pada penelitian ini dipilih 6 indikator berdasarkan penggunaan media Edmodo. Indikator-indikator yang akan digunakan yaitu, (1) mengunduh bahan ajar, (2) merumuskan pertanyaan, (3) mengunggah hasil pekerjaan ke dalam Edmodo, (4) memberikan tanggapan pada fitur polling, (5) mengerjakan soal yang diberikan guru, dan (6) mengumpulkan tugas tepat pada waktunya.

Menurut Hamalik (2007: 30) hasil belajar adalah sebagai terjadinya perubahan tingkah laku pada diri seseorang yang dapat diamati dan diukur dalam bentuk pengetahuan, sikap, dan keterampilan. Perubahan tersebut dapat diartikan sebagai terjadinya peningkatan dan pengembangan yang lebih baik dari sebelumnya dan yang tidak tahu menjadi tahu. Benyamin Bloom (dalam Sudjana, 2016: 22) membagi hasil belajar ke dalam 3 (tiga) ranah yaitu, Ranah Kognitif, Ranah Afektif, dan Ranah Psikomotorik.

Berdasarkan latar belakang di atas maka permasalahan dalam penelitian ini adalah bagaimana meningkatkan aktivitas dan hasil belajar pada mata pelajaran Pengelolaan Usaha Pemasaran siswa kelas X PM3 di SMK Negeri 1 Jember tahun ajaran 2016/2017. Berdasarkan rumusan masalah tersebut maka tujuan penelitian ini adalah untuk meningkatkan aktivitas dan hasil belajar pada mata pelajaran Pengelolaan Usaha Pemasaran di SMK Negeri 1 Jember melalui media pembelajaran Edmodo. 


\section{METODE}

Pembelajaran merupakan proses penyampaian informasi pengetahuan dari guru kepada siswa. Ciri-ciri pembelajaran pada dasarnya merupakan tanda-tanda upaya guru mengatur unsur-unsur dinamis dalam pembelajaran, sehingga dapat mengaktifkan siswa dalam kegiatan belajar mengajar agar terjadi proses belajar dan tujuan pembelajaran dapat tercapai. Kegiatan belajar mengajar merupakan suatu kondisi yang sengaja diciptakan dimana dalam kegiatan tersebut terjadi interaksi antara pendidik dan peserta didik guna mewujudkan tujuan pembelajaran itu sendiri.

Kegiatan pembelajaran yang dilakukan pada sekolah menengah kejuruan pada umumnya lebih mengarah kepada pengembangan kompetensi dan keterampilan. Sesuai dengan tujuan SMK adalah sebagai salah satu institusi yang menyiapkan tenaga kerja, dituntut mampu menghasilkan lulusan sebagaimana yang diharapkan oleh dunia kerja. Dengan demikian proses pembelajaran yang dilakukan oleh siswa SMK lebih cenderung secara praktikal, sehingga secara teori pengetahuan mereka lebih sedikit daripada pengalaman mereka ketika praktik.

Saat ini proses pembelajaran tatap muka masih sering digunakan. SMK Negeri 1 Jember juga merupakan salah satu sekolah yang menerapkan pembelajaran tatap muka dengan menggunakan media powerpoint. Penggunaan media powerpoint oleh guru masih belum cukup untuk menunjang kegiatan pembelajaran peserta didik. Berdasarkan observasi awal pada kelas X jurusan Pemasaran, aktivitas belajar kelas X PM3 termasuk dalam kategori rendah dibandingkan dengan kelas X PM1 dan X PM2. Aktivitas belajar pada kelas X PM3 hanya mencapai skor $40 \%$. Selain itu hasil belajar pada kelas X PM3 juga masih tergolong rendah, yakni rata-rata nilai ulangan harian masih di bawah KKM yaitu 66,7.

Media merupakan salah satu unsur yang dapat menunjang proses pembelajaran. Menurut Gerlach (dalam Sandjaya, 2012: 59) secara umum media (pembelajaran) itu meliputi orang, bahan, peralatan, atau kegiatan yang menciptakan kondisi yang memungkinkan siswa memperoleh pengetahuan, keterampilan, dan sikap. Jadi dalam pengertian ini media pembelajaran bukan hanya alat perantara, tetapi meliputi orang atau manusia sebagai sumber belajar atau juga berupa kegiatan semacam diskusi, simulasi, dan sebagainya yang dikondisikan untuk menambah pengetahuan dan wawasan, mengubah sikap peserta didik, serta untuk menambah keterampilan. Salah satu prinsip penggunaan media pembelajaran yang harus diperhatikan oleh guru menurut Sandjaya (2012: 75) bahwa media digunakan dan diarahkan untuk mempermudah siswa belajar dalam upaya memahami materi pelajaran.

Seiring dengan perkembangan Teknologi Informasi (TI), banyak diciptakan media yang dapat digunakan untuk menunjang kegiatan pembelajaran. Media pembelajaran berbasis internet atau $E$ Learning saat ini banyak digunakan untuk kegiatan belajar mengajar. Salah satu media yang dapat digunakan untuk menunjang kegiatan dalam pembelajaran yaitu Edmodo. Menurut Gatot (2013: 3) Edmodo adalah platform media sosial yang sering digambarkan seperti Facebook untuk sekolah dan dapat berfungsi lebih banyak lagi sesuai kebutuhan. Edmodo merupakan media yang menarik bagi guru dan peserta didik dengan elemen sosial yang menyerupai Facebook. Seorang guru dapat dengan mudah mengelola sebuah sistem yang menyediakan fitur terbaik dan praktis, sehingga guru selalu terhubung dengan peserta didik dan mengatur aktivitas peserta didik dengan mudah. Kegiatan pembelajaran yang dapat digunakan sesuai dengan fitur yang tersedia pada media Edmodo yakni contet sharing atau berbagi materi pelajaran, penugasan, kuis, polling serta memungkinkan adanya kegiatan diskusi pada fitur komentar.

Menurut Martinis Yamin (2007: 75) proses pembelajaran yang dilakukan di dalam kelas merupakan aktivitas mentransformasikan pengetahuan, sikap, dan keterampilan. Aktivitas merupakan prinsip atau asas yang sangat penting dalam interaksi belajar mengajar (Sardiman, 2006: 96). Pembelajaran akan menghasilkan suatu perubahan dan peningkatan kemampuan pengetahuan serta 
keterampilan pada diri peserta didik. Aktivitas belajar memiliki beberapa jenis dan indikator dimana pada penelitian ini dipilih 6 indikator berdasarkan penggunaan media Edmodo. Indikator-indikator yang akan digunakan yaitu, (1) mengunduh bahan ajar, (2) merumuskan pertanyaan, (3) mengunggah hasil pekerjaan ke dalam Edmodo, (4) memberikan tanggapan pada fitur polling, (5) mengerjakan soal yang diberikan guru, dan (6) mengumpulkan tugas tepat pada waktunya.

Menurut Hamalik (2007: 30) hasil belajar adalah sebagai terjadinya perubahan tingkah laku pada diri seseorang yang dapat diamati dan diukur dalam bentuk pengetahuan, sikap, dan keterampilan. Perubahan tersebut dapat diartikan sebagai terjadinya peningkatan dan pengembangan yang lebih baik dari sebelumnya dan yang tidak tahu menjadi tahu. Benyamin Bloom (dalam Sudjana, 2016: 22) membagi hasil belajar ke dalam 3 (tiga) ranah yaitu, Ranah Kognitif, Ranah Afektif, dan Ranah Psikomotorik.

Berdasarkan latar belakang di atas maka permasalahan dalam penelitian ini adalah bagaimana meningkatkan aktivitas dan hasil belajar pada mata pelajaran Pengelolaan Usaha Pemasaran siswa kelas X PM3 di SMK Negeri 1 Jember tahun ajaran 2016/2017. Berdasarkan rumusan masalah tersebut maka tujuan penelitian ini adalah untuk meningkatkan aktivitas dan hasil belajar pada mata pelajaran Pengelolaan Usaha Pemasaran di SMK Negeri 1 Jember melalui media pembelajaran Edmodo.

\section{HASIL DAN PEMBAHASAN}

\section{Hasil Penelitian}

Pada kondisi awal aktivitas dan hasil belajar kelas X PM 3 rendah, siswa dalam mengikuti pembelajaran di kelas masih kurang aktif. Siswa belum berani mengajukan pertanyaan, mengemukakan pendapat dan berlatih soal-soal. Hal tersebut dijadikan tolok ukur untuk meningkatkan aktivitas dan hasil belajar siswa sehingga didapatkan proses dan hasil pembelajaran yang lebih baik. Berikut ini merupakan tabel aktivitas dan hasil belajar siswa kelas X jurusan Pemasaran pada Observasi awal:

Tabel Aktivitas Belajar Siswa Pada Observasi Awal

\begin{tabular}{|c|l|c|c|c|}
\hline No. & \multicolumn{1}{|c|}{ Kelas } & Jumlah Siswa & $\begin{array}{c}\text { Persentase Aktivitas Bela- } \\
\text { jar }\end{array}$ & Kriteria \\
\hline 1 & X PM1 & 40 & $77 \%$ & Aktif \\
\hline 2 & X PM2 & 39 & $65 \%$ & Aktif \\
\hline 3 & X PM3 & 39 & $44 \%$ & Kurang Aktif \\
\hline
\end{tabular}

Tabel Hasil Belajar Siswa Pada Observasi Awal

\begin{tabular}{|c|c|c|}
\hline No. & Kelas & Rata-rata Nilai \\
\hline 1. & X PM 1 & 74,9 \\
\hline 2. & X PM 2 & 74,6 \\
\hline 3. & X PM 3 & 66,7 \\
\hline
\end{tabular}

Berdasarkan tabel diatas, skor aktivitas tertinggi pada kelas X PM 1 dan skor terendah pada kelas X PM 3. Hasil belajar pada observasi awal, menunjukkan bahwa nilai rata-rata tertinggi pada kelas X PM 1 dengan nilai 74,9 dan terendah pada kelas X PM 3 dengan nilai rata-rata 66,7. Hasil observasi awal tersebut menunjukkan bahwa aktivitas dan hasil belajar terendah terjadi pada kelas X PM 3. Sesuai dengan hasil observasi awal dan rekomendasi dari guru, maka perlu adanya peningkatan kualitas pembelajaran pada kelas X PM 3.

Pelaksanaan penelitian pada siklus 1 dan siklus 2 dilakukan pada jam mata pelajaran Pengelolaan Usaha Pemasaran dengan menggunakan media pembelajaran Edmodo. Kegiatan yang diteliti untuk 
mengukur aktivitas belajar siswa adalah mengunduh bahan ajar, merumuskan pertanyaan, mengunggah hasil pekerjaan ke dalam Edmodo, memberikan tanggapan pada fitur polling, mengumpulkan tugas tepat pada waktunya, dan mengerjakan soal-soal dalam Edmodo. Hasil observasi aktivitas belajar pada siklus 1 dan 2 menunjukkan adanya peningkatan sebesar 60,7\% dan 92,5\%. Hal tersebut dapat ditunjukkan dengan data pada tabel berikut ini:

Tabel Data Hasil Observasi Aktivitas Belajar Siklus 1 dan Siklus 2

\begin{tabular}{|l|l|c|c|r|}
\hline No. & \multicolumn{1}{|c|}{ Indikator } & $\begin{array}{c}\text { Sebelum } \\
\text { Tindakan }\end{array}$ & Siklus 1 & Siklus 2 \\
\hline 1. & Mengunduh bahan ajar & $52 \%$ & $77,8 \%$ & $97,4 \%$ \\
\hline 2. & Merumuskan pertanyaan & $37 \%$ & $40,2 \%$ & $84,6 \%$ \\
\hline 3. & $\begin{array}{l}\text { Mengunggah hasil pekerjaan ke dalam } E d- \\
\text { modo }\end{array}$ & $54 \%$ & $72,6 \%$ & $94,0 \%$ \\
\hline 4. & Memberikan tanggapan pada fitur polling & $44 \%$ & $58,1 \%$ & $93,2 \%$ \\
\hline 5. & $\begin{array}{l}\text { Mengumpulkan tugas tepat pada wak- } \\
\text { tunya }\end{array}$ & $37 \%$ & $51,3 \%$ & $88,0 \%$ \\
\hline 6. & Mengerjakan soal-soal melalui Edmodo & $43 \%$ & $64,1 \%$ & $97,4 \%$ \\
\hline & Rata-rata Aktivitas Belajar Siswa & $44 \%$ & $60,7 \%$ & $92,5 \%$ \\
\hline
\end{tabular}

Berdasarkan data pada tabel diatas, maka aktivitas belajar siswa menunjukkan adanya peningkatan dari skor pada kondisi awal sebelum adanya tindakan. Skor pada kondisi awal sebesar $44 \%$ dengan kategori kurang aktif, menjadi 92,5\% pada siklus 2 dengan kategori sangat aktif.

Hasil belajar pada siklus 1 dan siklus 2 juga menunjukkan adanya peningkatan dari sebelumnya. Berdasarkan evaluasi pembelajaran yang dilakukan pada pertemuan kedua diperoleh hasil belajar dengan rata-rata nilai sebesar 72,37 pada siklus 1 dan 80,10 pada siklus 2 . Hal ini menunjukkan adanya peningkatan dari kondisi awal rata-rata nilai kelas X PM 3 sebesar 66,79. Berikut ini tabel hasil nilai rata-rata siswa kelas X PM 3 pada siklus 1:

Tabel Hasil Belajar Siswa pada Siklus 1 dan Siklus 2

\begin{tabular}{|l|c|}
\hline \multicolumn{1}{|c|}{ Uraian } & Nilai Rata-rata \\
\hline Kondisi Awal & 66,7 \\
\hline Siklus 1 & 72,37 \\
\hline Siklus 2 & 80,10 \\
\hline
\end{tabular}

(Sumber : Data primer diolah)

Berdasarkan data diatas maka dapat disimpulkan bahwa terjadi peningkatan dari kondisi awal nilai rata-rata sebesar 66,7 menjadi 72,37 pada siklus 1 dan 80,10 pada siklus 2 . Peningkatan dari kondisi awal ke siklus 1 dapat ditunjukkan dengan diagram berikut: 
Diagram Peningkatan Hasil Belajar Siswa pada Siklus 1

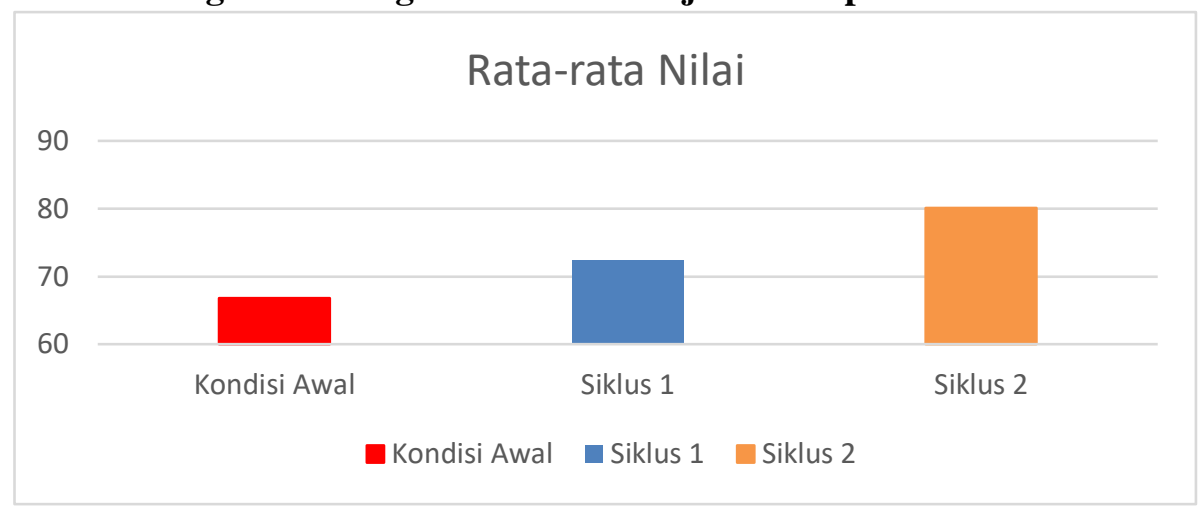

\section{Pembahasan}

Hasil penelitian menunjukkan bahwa penggunaan media Edmodo dengan efektif meningkatkan aktivitas dan hasil belajar siswa pada mata pelajaran Pengelolaan Usaha Pemasaran siswa kelas X PM 3 di SMK Negeri 1 Jember. Aktivitas belajar siswa berupa aktivitas mengunduh bahan ajar, merumuskan pertanyaan, mengunggah hasil pekerjaan, memberikan tanggapan, mengumpulkankan tugas tepat pada waktunya dan mengerjakan soal-soal meningkat dari kategori kurang aktif menjadi sangat aktif. Hasil belajar siswa juga membuktikan bahwa siswa kelas X PM 3 dapat mencapai ketuntasan kelas yaitu rata-rata nilai sebesar 80,10 mampu mencapai KKM sekolah yaitu 70. Hal ini membuktikan bahwa hipotesis yang diajukan dalam penelitian ini terbukti.

\section{PENUTUP}

Berdasarkan penelitian dan analisis data yang dilakukan dapat diketahui bahwa penelitian tindakan kelas tentang penggunaan media pembelajaran Edmodo pada siswa kelas X Pemasaran di SMK Negeri 1 Jember dapat meningkatkan aktivitas dan hasil belajar. Skor aktivitas belajar siswa sebelum adanya tindakan menggunakan media Edmodo sebesar 44\%, sedangkan skor aktivitas belajar siswa pada siklus 1 sebesar 60,7\% dan skor pada siklus 2 sebesar 92,5\% yang masuk ke dalam kategori sangat aktif.

Penggunaan media pembelajaran Edmodo juga dapat meningkatkan hasil belajar siswa. Hasil belajar siswa sebelum adanya tindakan menggunakan media Edmodo memiliki rata-rata nilai sebesar 66,79, pada siklus 1 rata-rata nilai sebesar 72,37, dan pada siklus 2 rata-rata nilai sebesar 80,10. Hasil belajar siswa kelas X PM3 di SMK Negeri 1 Jember mengalami peningkatan setelah penggunaan media pembelajaran Edmodo.

Berdasarkan hasil dan pembahasan, maka saran yang dapat peneliti berikan adalah (1) Bagi guru, hendaknya terus meningkatkan kemampuan penggunaan media Edmodo serta terus memberikan variasi pembelajaran yang diterapkan di kelas, (2) Bagi sekolah, lebih meningkatkan fasilitas sekolah terutama media pembelajaran internet untuk menunjang proses pembelajaran di sekolah serta lebih meningkatkan perhatian terhadap aktivitas siswa dalam belajar karena dapat mempengaruhi hasil belajar siswa.

\section{DAFTAR PUSTAKA}

Hamalik, Oemar. 2007. Proses Belajar Mengajar. Jakarta: Bumi Aksara.

Priowijanto, Gatot. 2013. Materi Simulasi Digital. Jakarta: Seamolec.

Sandjaya, Wina. 2012. Media Komunikasi Pembelajaran. Jakarta: Kencana. 
Sardiman, A.M. 2006. Interaksi dan Motivasi Belajar Mengajar. Jakarta: Raja Grafindo Persada.

Yamin, Martinis. 2007. Strategi pembelajaran berbasis kompetensi. Jakarta: GP Press. 